\title{
FUMIGATION TOXICITY OF ESSENTIAL OILS AGAINST Rhyzopertha dominica (F.) IN STORED MAIZE GRAIN ${ }^{1}$
}

\author{
VALDEANY NÚBIA DE SOUZA ${ }^{2}$, CARLOS ROMERO FERREIRA DE OLIVEIRA*2, CLÁUDIA HELENA \\ CYSNEIROS MATOS ${ }^{2}$, DAIANY KEILA FLORENTINO DE ALMEIDA ${ }^{2}$
}

\begin{abstract}
The Rhyzopertha dominica F. (Coleoptera: Bostrichidae) is a primary pest of stored grains in many regions of the world. In this work we evaluated the fumigant activity of essential oils of Ocimum basilicum L., Citrus aurantium L., Mentha spicata L. and Croton pulegiodorus Baill on adult R. dominica in stored maize. Tests were conducted to determine lethals concentrations $\left(\mathrm{CL}_{50}\right.$ and $\left.\mathrm{CL}_{100}\right)$ and mortality (fumigation). The fumigation test was done in containers made of glass containing 10 individuals of $R$. dominica, where essential oils were applied at different concentrations: O. basilicum and M. spicata (5, 10, 15, 20,30 and $40 \mu \mathrm{L} / \mathrm{L}$ of air), C. aurantium $(10,20,30,40,50$ and $60 \mu \mathrm{L} / \mathrm{L}$ of air) and C. pulegiodorus $(0,20,30$, 50,70 and $90 \mu \mathrm{L} / \mathrm{L}$ of air). After 48 hours of exposure to the oils the percentage of insect mortality was evaluated. According to $\mathrm{LC}_{50}$ and $\mathrm{LC}_{100}$ the toxicity of essential oils decreased in the following order: $O$. basilicum $>M$. spicata $>C$. pulegiodorus $>C$. aurantium. The essential oil of $O$. basilicum exhibited strong fumigant toxicity against $R$. dominica adults, with a $\mathrm{LC}_{50}$ value of $17.67 \mu \mathrm{L} / \mathrm{L}$ air and $\mathrm{LC}_{100}$ value of $27.15 \mu \mathrm{L} /$ $\mathrm{L}$ air. The $C$. aurantium essential oil required higher concentrations than $O$. basilicum, M. spicata and $C$. pulegiodorus to kill insects. However, all oils evaluated presented fumigating property to promote the control of $R$. dominica and demonstrated potential use in the management of this coleoptera.
\end{abstract}

Keywords: Botanical insecticides. Fumigant effect. Bostrichidae. Stored grains.

\section{TOXICIDADE POR FUMIGAÇÃO DE ÓLEOS ESSENCIAIS SOBRE Rhyzopertha dominica (F.) EM GRÃOS DE MILHO ARMAZENADOS}

\begin{abstract}
RESUMO - Rhyzopertha dominica F. (Coleoptera: Bostrichidae) é uma praga primária de grãos armazenados em muitas regiões do mundo. Este trabalho teve como objetivo avaliar a atividade fumigante dos óleos essenciais de Ocimum basilicum L., Citrus aurantium L., Mentha spicata L. e Croton pulegiodorus Baill. sobre adultos de $R$. dominica em grãos de milho armazenados. Para isso, testes para determinação das concentrações letais $\left(\mathrm{CL}_{50}\right.$ e $\left.\mathrm{CL}_{100}\right)$ e mortalidade (fumigação) foram realizados em câmaras constituídas por recipientes de vidro, contendo 10 indivíduos de $R$. dominica, com óleos essenciais em diferentes concentrações: $O$. basilicum e $M$. spicata $(5,10,15,20,30$ e $40 \mu \mathrm{L} / \mathrm{L}$ de ar), $C$. aurantium $(10,20,30,40,50$ e $60 \mu \mathrm{L} / \mathrm{L}$ de ar) e $C$. pulegiodorus $(0,20,30,50,70$ e $90 \mu \mathrm{L} / \mathrm{L}$ de ar). Após $48 \mathrm{~h}$ de exposição aos óleos, avaliou-se a percentagem de mortalidade dos insetos. Com base nas $\mathrm{CL}_{50}$ e $\mathrm{CL}_{100}$, a toxicidade dos óleos essenciais decresceu na seguinte ordem: $O$. basilicum $>M$. spicata $>C$. pulegiodorus $>C$. aurantium. O óleo essencial de $O$. basilicum exibiu forte toxicidade por fumigação sobre adultos de $R$. dominica, com valores de $\mathrm{CL}_{50}$ de $17,67 \mu \mathrm{L} / \mathrm{L}$ de ar e de $\mathrm{CL}_{100}$ de $27,15 \mu \mathrm{L} / \mathrm{L}$ de ar. O óleo essencial de $C$. aurantium requereu concentrações mais altas que os óleos de O. basilicum, M. spicata e C. pulegiodorus para matar os insetos. Contudo, todos os óleos avaliados apresentaram propriedades fumigantes para controlar a $R$. dominica e demonstraram potencial de utilização no manejo deste coleóptero.
\end{abstract}

Palavras-chave: Inseticidas botânicos. Efeito fumigante. Bostrichidae. Grãos armazenados.

\footnotetext{
*Corresponding author

${ }^{1}$ Received for publication in 05/09/2015; accepted in 02/06/2016.

Paper extracted from the masters thesis of the first author.

${ }^{2}$ Academic Unit of Serra Talhada, Universidade Federal Rural de Pernambuco, Serra Talhada, PE, Brazil; valdeanynubia@gmail.com,crfoliveira@hotmail.com,ccysne@hotmail.com, daianykeila_@hotmail.com.
} 


\section{INTRODUCTION}

Maize is very important as it constitutes a staple food for humans and animals, and is the most consumed cereal worldwide. Maize production is among the main agricultural activities practiced in Brazil (CONAB, 2012). However, many maize farmers are small-scale farmers who grow low-input crops by planting seeds saved in one year during the next, usually intercropped with other species. In this sense, it favors the incidence of pests that cause large losses by attacking at all stages of their cycle (NÉRI et al., 2005; OLIVEIRA et al., 2007).

Damage incurred by stored grain is definitive and unrecoverable, since pest feeding causes qualitative and quantitative losses, such as grain weight loss, decrease in nutritional value and germination capacity of seeds, and product devaluation (GALLO et al., 2002; LORINI, 2008; SCHEEPENS et al., 2011). Of the insect pests that affect maize during storage, Sitophilus zeamais Motsch. (Coleoptera: Curculionidae), Sitophilus oryzae L. (Coleoptera: Curculionidae), Rhyzopertha dominica F. (Coleoptera: Bostrichidae), and Ephestia kuehniella Zeller (Lepidoptera: Pyralidae) are responsible for physical, physiological, and sanitary deterioration (LORINI, 2008).

The $R$. dominica beetle is notable because it attacks various cereals and is considered one of the most destructive corn pests owing to its high incidence and the great difficulty in avoiding the losses that it causes to grains (LORINI, 2008). This insect is mainly controlled using synthetic insecticides (organophosphates or pyrethroids) and fumigation, phosphine being remarkable as the main fumigant used (LORINI; GALLEY, 1999; GONÇALVES et al., 2007). However, studies revealed phosphine resistance in Brazilian $R$. dominica populations (ATHIÉ et al., 2001; PIMENTEL et al., 2008), which could render the use of these products unviable if alternative methods are not implemented.

Recently, studies with powders, essential oils, and plant-based extracts have been developed in integrated pest management programs, mainly for the control of Callosobruchus maculatus (Coleoptera: Chrysomelidae), $R$. dominica, and $S$. zeamais (ALMEIDA et al., 2005; BRITO et al., 2006; NAIMA et al., 2013). In Brazil, there are various plant families with insecticidal action that can be used for their essential oils, such as, Piperaceae, Myrtaceae, Lauraceae, Euphorbiaceae, Verbenaceae, Lamiaceae, Rutaceae, and Poaceae (COITINHO et al., 2011).

The genera Ocimum and Mentha, belonging to the family Lamiaceae, have recently been investigated with regard to their insecticidal properties against diverse insect pests (KÉITA et al., 2001; KHALFI et al., 2006; LOPEZ et al., 2008; OGENDO et al., 2008; BENAYAD et al., 2012;
ESMAILI et al., 2013). Similarly, essential oils of the genus Citrus, family Rutaceae, have been described to have insecticidal properties against insect pests of stored grains (PRATES et al., 1998; FOROUZAN et al., 2013; RINGUELET et al., 2014). Several studies involving the family Euphorbiaceae have been also conducted to evaluate its potential in essential oil production, the genus Croton being the most tested in controlling insect pests (BRITO, 2014; MAGALHÃES, 2014). However, there is still no information about the use of these essential oils against $R$. dominica in Brazil.

In this context, the present study aims to evaluate the insecticidal effect of essential oils of basil (Ocimum basilicum), bitter orange (Citrus aurantium), spearmint (Mentha spicata), and "velaminho" (Croton pulegiodorus) on $R$. dominica adults by fumigation of stored maize grains.

\section{MATERIAL AND METHODS}

The study was performed at the Entomology Laboratory of the Serra Talhada Academic Unit (UAST)/Federal Rural University of Pernambuco (UFRPE), Brazil, and the following steps were conducted:

a) Elimination of infestation and balance of grain moisture content - maize grains, 2013/14 crop season, from farmers of Serra Talhada, PE $\left(07^{\circ} 59^{\prime}\right.$ $31^{\prime \prime} \mathrm{S}, 38^{\circ} 17^{\prime} 54^{\prime \prime} \mathrm{W}$, and $\left.429 \mathrm{~m}\right)$, were used for rearing and bioassays with $R$. dominica. For this, the grains were cleaned (sieved), dried, and placed in plastic bags and kept in a freezer $\left(-10^{\circ} \mathrm{C}\right)$ for 7 days, to eliminate subsequent infestations of insects from the field. After this period, the grains were placed in glass flasks and kept at room temperature $\left(28 \pm 2{ }^{\circ} \mathrm{C}\right.$ and $65 \pm 5 \%$ moisture content).

b) $R$. dominica rearing - the insects were reared in maize grains at $30 \pm 2{ }^{\circ} \mathrm{C}, 60 \%$ relative humidity, and 12-hour photoperiod, in biochemical oxygen demand (BOD) climatic chambers, placed in closed containers with perforated plastic lids and the inside lined with thin material to allow gas exchange. They remained confined for 7 days to induce oviposition and were then removed and the containers stored until emergence of the next generation. This procedure was performed for five generations to ensure the number of adults necessary to execute the experiments.

c) Essential oil obtainment - essential oils of basil ( $O$. basilicum), bitter orange ( $C$. aurantium), and spearmint $(M$. spicata) were acquired from the company Terra-Flor Indústria e Comércio de Aromaterápicos Ltda. Basil essential oil was obtained by the vapor distillation extraction method using the leaves; spearmint essential oil was obtained by vapor distillation using the stems and leaves; bitter orange essential oil was obtained by cold pressing the peels. The plant material used to 
produce essential oil of "velaminho" $(C$. pulegiodorus $)$ was harvested at Triunfo, $\mathrm{PE}\left(07^{\circ} 50^{\prime}\right.$ $17^{\prime \prime} \mathrm{S}, 38^{\circ} 06^{\prime} 06^{\prime \prime} \mathrm{W}$, and $\left.1004 \mathrm{~m}\right)$, Brazil. The species was identified by a specialist of the Brazilian Semiarid Herbarium (HESBRA), which was deposited under Voucher - S.S. Matos 104. "Velaminho" essential oil was extracted from fresh leaves by hydrodistillation using a modified Clevenger equipment, with $200 \mathrm{~g}$ in $3 \mathrm{~L}$ of distilled water for 2 hours. The obtained fractions were separated from water by dichloromethane and dried with anhydrous sodium sulfate $\left(\mathrm{Na}_{2} \mathrm{SO}_{4}\right)$, and then placed in a rota-evaporator, where dichloromethane was removed, obtaining the essential oil.

Chromatography provided by the Terra-Flor company indicates that the basil essential oil exhibited estragole $(72.67 \%)$ and linalool $(22.41 \%)$ as major compounds. The spearmint essential oil mainly comprised menthol (35.20\%), isomenthone $(18.71 \%)$, and menthyl acetate $(6.22 \%)$. Bitter orange essential oil exhibited limonene $(90.78 \%)$ and myrcene $(3.87 \%)$ as main compounds. According to Dória et al. (2010), "velaminho" essential oil had $\beta$ caryophyllene (20.96\%), bicyclogermacrene $(16.89 \%)$, and germacrene D $(10.55 \%)$ as major components.

d) Fumigation - to evaluate the fumigant effect, glass containers (bomboniere) were used as fumigation chambers $(1 \mathrm{~L})$, where $10 \mathrm{R}$. dominica adults were confined. Preliminary tests were conducted with all essential oils, in which several concentrations were evaluated, including intermediaries, with less replicates, and the most promising were used in the definitive tests. Based on the preliminary tests, essential oils were tested at the following concentrations: basil $(5,10,15,20,30$, and $40 \mu \mathrm{L} / \mathrm{L}$
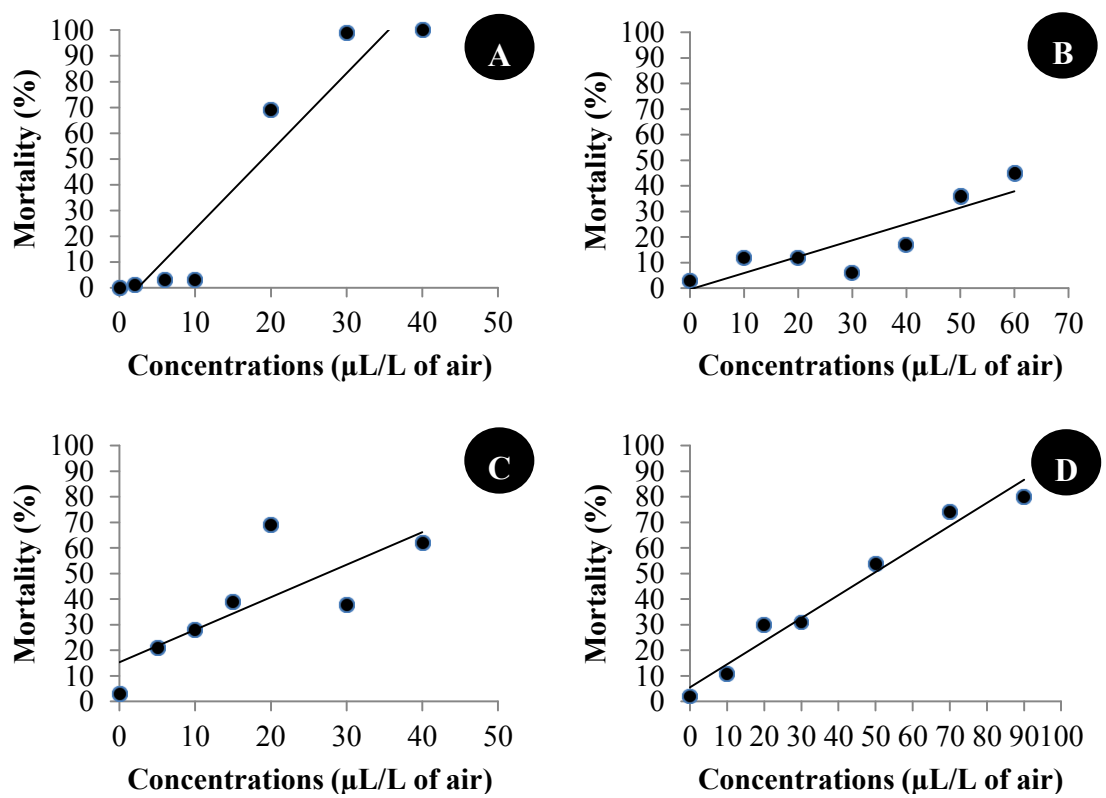

Figure 1. Mortality of Rhyzopertha dominica following fumigation with different concentrations of the essential oil of Ocimum basilicum: $\mathrm{y}=3.0262 \mathrm{x}-7.4043$ and $\mathrm{R}^{2}=0.9131$ (A); Citrus aurantium: $\mathrm{y}=0.6393 \mathrm{x}-0.4643$ and $\mathrm{R}^{2}=0.7673$ (B); Mentha spicata: $\mathrm{y}=1.2683 \mathrm{x}-$ 15.401 and $\mathrm{R}^{2}=0.6097(\mathrm{C})$; and Croton pulegiodorus: $\mathrm{y}=0.9009 \mathrm{x}+5.5374$ and $\mathrm{R}^{2}=0.9716$ (D) 
According to the determined lethal concentrations $\left(\mathrm{LC}_{50}\right.$ and $\left.\mathrm{LC}_{100}\right)$, toxicity of the essential oils decreased in the following order: $O$. basilicum $>$ M. spicata $>C$. pulegiodorus $>C$. aurantium (Table 1). The essential oils of $O$. basilicum and $M$. spicata exhibited the lowest $\mathrm{LC}_{50}$ values, which resulted in higher toxicities achieved at lower concentrations, leading to $50 \%$ mortality. $\mathrm{LC}_{100}$ followed the same principle, with the highest toxicities achieved for the essential oils of $O$. basilicum and M. spicata, exhibiting the lowest concentrations, leading to $100 \%$ mortality. The toxicity ratio (TR) values were between 3.93 and 1.42 (Table 1). All tested essential oils exhibited potential to cause mortality in $R$. dominica; however, the essential oils of $C$. pulegiodorus and $C$. aurantium required higher concentrations to reach this goal

Table 1. Toxicity (fumigation) of essential oils of Citrus aurantium, Croton pulegiodorus, Mentha spicata, and Ocimum basilicum against Rhyzopertha dominica in stored maize grains.

\begin{tabular}{|c|c|c|c|c|c|c|c|}
\hline Essential oils & $\mathrm{N}$ & $\begin{array}{c}\text { Angular coefficient } \\
\pm \text { SEM }\end{array}$ & $\begin{array}{c}\mathrm{LC}_{50} \\
(95 \% \mathrm{CI}) \\
\mu \mathrm{L} / \mathrm{L} \text { of air }\end{array}$ & $\begin{array}{c}\mathrm{LC}_{100} \\
(95 \% \mathrm{CI}) \\
\mu \mathrm{L} / \mathrm{L} \text { of air }\end{array}$ & $\begin{array}{c}\mathrm{TR} \\
\left(\mathrm{LC}_{50}\right)\end{array}$ & $X^{2}$ & $P$ \\
\hline C. aurantium & 700 & $0.0245 \pm 0.0125$ & 69.36 & 130.68 & - & 23.12 & 0.0001 \\
\hline C. pulegiodorus & 700 & $0.0242 \pm 0.0075$ & 48.66 & 110.57 & 1.42 & 3.30 & 0.0001 \\
\hline M. spicata & 700 & $0.0255 \pm 0.0163$ & 27.51 & 86.31 & 2.52 & 16.92 & 0.0001 \\
\hline O. basilicum & 700 & $0.1583 \pm 0.0294$ & 17.67 & 27.15 & 3.93 & 73.47 & 0.0001 \\
\hline
\end{tabular}

$\mathrm{N}=$ number of individuals; $\mathrm{SEM}=$ standard error of the mean; $\mathrm{CI}=$ confidence interval; $\mathrm{TR}=$ toxicity ratio; $\chi^{2}=$ chisquare; $\mathrm{P}=$ probability.

Several studies with essential oils from species of the genus Ocimum exhibited satisfactory results regarding their insecticidal effect against insect pests. Kéita et al. (2001) evaluated the fumigant effect of $O$. basilicum and $O$. gratissimum in controlling C. maculatus and obtained 80 and $70 \%$ mortality with $25 \mu \mathrm{L}$, respectively. Rozman et al. (2007) reported toxicity against Tribolium castaneum Herbst (Coleoptera: Tenebrionidae), $R$. dominica, and $S$. oryzae in fumigation with linalool. For $R$. dominica, linalool was highly effective and caused $100 \%$ mortality at the lowest used concentration $(0.1$ $\mathrm{mL} / 720 \mathrm{~mL}$ of volume). Ogendo et al. (2008) obtained 98, 99, and 100\% mortality, respectively, against $R$. dominica, Oryzaephilus surinamensis L. (Coleoptera: Silvanidae), and Callosobruchus chinensis L. (Coleoptera: Chrysomelidae), in using 1 $\mu \mathrm{L} / \mathrm{L}$ of air of $O$. gratissimum essential oil.

Relevant results have been described for Mentha essential oils in controlling diverse pests of stored products. Khalfi et al. (2006) observed an insecticidal effect of the composition of $M$. spicata essential oil in different proportions of 1.8 cineol and carvone against $R$. dominica. The results indicated that insecticidal activity of this essential oil led to a synergistic effect of both compounds, since composition of the essential oil differed depending on the extraction time. Benayad et al. (2012) evaluated the chemical composition and insecticidal effect of essential oils of $M$. suaveolens and $M$. pulegium against $S$. oryzae and $R$. dominica. The essential oils were very toxic for the two Coleoptera species within the first 24 hours, with $100 \%$ mortalities when $50 \mu \mathrm{L}$ and $12 \mu \mathrm{L}$ were used, respectively.

The essential oils of bitter orange and "velaminho" exhibited higher concentrations than did the other oils used to cause mortality in $R$. dominica. Essential oils from fruit peels of some citrus species were reported to have insecticidal properties against insect pests of stored grains. Prates et al. (1998) evaluated cineol (from Eucalyptus spp.) and limonene (from Citrus spp.) to determine possible fumigant activity, contact, and ingestion against $R$. dominica and $T$. castaneum. These authors observed that limonene was more effective against $T$. castaneum than $R$. dominica. The toxic effects of these substances are mediated by penetrating the insect body through the respiratory system (via a fumigant), the cuticle (by contact), or the digestive system (via ingestion). Forouzan et al. (2013) evaluated the potential of essential oil from Citrus reticulata peels against $R$. dominica during different exposure periods and concluded that this essential oil was indicated as a good fumigant against adults of this insect.

Brito (2014) evaluated the effect of essential oils of $C$. pulegiodorus and $O$. basilicum on $C$. maculatus and Zabrotes subfasciatus Boh. (Coleoptera: Chrysomelidae) at different concentrations $(0.0,5,10,15$, and $20 \mu \mathrm{L} / \mathrm{L}$ of air). According to this author, the fumigant effect of $O$. basilicum caused $100 \%$ mortality in C. maculatus, but there was no significant difference for the concentrations of $C$. pulegiodorus essential oil. According to the same author, $100 \%$ mortality in $Z$. 
subfasciatus was observed for all used concentrations of both essential oils. Using essential oils of $C$. pulegiodorus and $O$. basilicum against $S$. zeamais and T. castaneum, Magalhães (2014) observed $90 \%$ mortality in $S$. zeamais at $20 \mu \mathrm{L}$ concentration of $C$. pulegiodorus essential oil. On the other hand, there was no significant difference between the tested concentrations against $T$. castaneum. Campos et al. (2014) observed 100\% mortality in C. maculatus adults using essential oil of Baccharis articulata.

Insect mortality is only one of the effects to be achieved in pest control with insecticidal plants (HUANG et al., 2002; KETOH et al., 2005). According to these authors, these plants also affect feeding, oviposition, and growth, and lead to decrease in the emergence of adults, among other effects not occurring with conventional insecticides, which are usually more toxic and cause insect mortality only.

\section{CONCLUSIONS}

Essential oils of $O$. basilicum, $C$. pulegiodorus, and M. spicata, at the highest concentrations, cause mortality higher than $70 \%$ in $R$. dominica, whereas the essential oil of $C$. aurantium causes mortality lower than $45 \%$.

Oils of $O$. basilicum and $M$. spicata exhibit the lowest $\mathrm{LC}_{50}$ and $\mathrm{LC}_{100}$ values for mortality of $R$. dominica.

All studied oils in the fumigation bioassays demonstrate potential to control $R$. dominica.

\section{ACKNOWLEDGEMENTS}

The authors would like to thank UFRPE, FACEPE and CNPq for financial support.

\section{REFERENCES}

ALMEIDA, F. A. C. et al. Efeito de extratos alcoólicos de plantas sobre o caruncho do feijão vigna (Callosobruchus maculatus). Revista Brasileira de Engenharia Agrícola e Ambiental, Campina Grande, v. 9, n. 4, p. 585-590. 2005.

ATHIÉ, I. et al. Resistência à fosfina de insetos de grãos armazenados determinada por cromatografia gasosa. Brazilian Jornal of Food Technolgy, Campinas, v. 4, n. único, p. 43-47, 2001.

BENAYAD, N. et al. Chemical characterization and Insecticidal evaluation of the essential oil of Mentha suaveolens L. and Mentha pulegium L. growing in Morocco. Scientific Study and Research:
Chemistry and Chemical Engineering, Biotechnology, Food Industry, Bacau, v. 13, n. 1, p. 27-32, 2012.

BRITO, J. P.; OLIVEIRA, J. E. M.; BORTOLI, S. A. Toxicidade de óleos essenciais de Eucalyptus spp. sobre Callosobruchus maculatus (Fabr., 1775) (Coleoptera: Bruchidae). Revista de Biologia e Ciências da Terra, São Cristóvão, v. 6, n. 1, p. 96103, 2006.

BRITO, S. S. S. Manejo de coleópteros-praga de feijão armazenado com óleos essenciais. 2014. 99 f. Dissertação (Mestrado em Produção Agrícola: Área de Concentração em Produção Agrícola) Universidade Federal Rural de Pernambuco, Garanhuns, 2014.

CAMPOS, A. C. T. et al. Atividade repelente e inseticida do óleo essencial de carqueja doce sobre o caruncho do feijão. Revista Brasileira de Engenharia Agrícola e Ambiental, Campina Grande, v. 18, n. 8, p. 861-865, 2014

COITINHO, R. L. B. C. et al. Toxicidade por fumigação, contato e ingestão de óleos essenciais para Sitophilus zeamais Motschulsky, 1885 (Coleoptera: Curculionidae). Ciência e Agrotecnologia, Lavras, v. 35, n. 1, p. 172-178, 2011

CONAB - Companhia Nacional de Abastecimento. Acompanhamento de safra brasileira: grãos. Brasília: CONAB, v. 2, n. 11, p. 1-101, 2014.

DÓRIA, G. A. et al. Study of the larvicidal activity of two Croton species from northeastern Brazil against Aedes aegypti. Pharmaceutical Biology, New York, v. 48, n. 6, p. 615-620, 2010.

ESMAILI, M.; VOJOUDI, S.; PARSAEYAN, E. Fumigant toxicity of essential oils of Mentha pulegium L. on adults of Callosobruchus maculatus, Tribolium castaneum, Lasioderma serricorne and Sitophilus oryzae in laboratory conditions. Technical Journal of Engineering and Applied Sciences, Giza, v. 3, n. 9, p. 732-735, 2013.

FOROUZAN, M. et al. Fumigant toxicity of essential oils from citrus reticulate Blanco fruit peels against Rhyzopertha dominica F. (Col.:Bostrichidae). Scientia Agriculturae, Naya Lahore, v. 1, n. 3, p. 67 $-69,2013$.

GALLO, D. et al. Entomologia agrícola. 10. ed. Piracicaba, SP: FEALQ, 2002. 920 p.

GONÇALVES, J. R. et al. Susceptibilidade de Rhyzopertha dominica (Fabricius) (Coleoptera: Bostrichidae) ao enxofre. Ciência Rural, Santa 
Maria, v. 37, n. 4, p. 1145-1148, 2007.

HUANG, Y. et al. Insecticidal properties of eugenol, isoeugenol and methyleugenol and their effects on nutrition of Sitophilus zeamais Mots. (Coleoptera: Curculionidae) and Tribolium castaneum (Herbst.) (Coleoptera: Tenebrionidae). Journal of Stored Products Research, Manhattan, v. 38, n. 5, p. 403412, 2002.

KÉITA, S. M. et al. Efficacy of essential oil of Ocimum basilicum L. and $O$. gratissimum L. applied as an insecticidal fumigant and powder to control Callosobruchus maculatus (Fab.) (Coleoptera: Bruchidae). Journal of Stored Products Research, Manhattan, v 37, n. 4, p. 339-349, 2001.

KETOH, G. K.; HONORE. K. K.; GLITHO, I. A. Inhibition of Callosobruchus maculatus (F.) (Coleoptera: Bruchidae) development with essencial oil extracted from Cymbopogon schoenanthus L. Spreng. (Poaceae), and the wasp Dinarmus basalis (Rondani) (Hymenoptera: Pteromalidae). Journal of Stored Products Research, Manhattan, v. 41, n. 4, p. $363-371,2005$.

KHALFI, O. et al. Extraction, Analysis and Insecticidal Activity of Spearmint Essential Oil from Algeria Against Rhyzopertha dominica (F.). Journal of Essential Oil-Bearing Plants, Prem Nagar, v. 9, n. 1, p. 17-21, 2006.

LOPEZ, M. D.; JORDAN, M. J.; PASCUALVILLALOBOS, M. J. Toxic compounds in essential oils of coriander, caraway and basil active against stored rice pests. Journal of Stored Products Research, Manhattan, v. 44, n. 3, p. 273-278, 2008.

LORINI, I. Manejo integrado de pragas de grãos de cereais armazenados. 1. ed. Passo Fundo, RS: Embrapa Trigo, 2008. 72 p.

LORINI, I.; GALLEY, D. J. Deltamethrin resistance in Rhyzopertha dominica (F.) (Coleoptera: Bostrichidae), a pest of stored grain in Brazil. Journal of Stored Products Research, Manhattan, v. 35, n. 1, p. 37-45, 1999.

MAGALHÃES， C. R. I. Utilização de óleos essenciais no controle de Sitophilus zeamais Mots. (Coleoptera: Curculionidae) e Tribolium castaneum Herbst. (Coleoptera: Tenebrionidae) em milho armazenado. 2014. 72 f. Dissertação (Mestrado em Produção Vegetal: Área de Concentração em Produção Vegetal no Semiárido), Universidade Federal Rural de Pernambuco, Serra Talhada, 2014

NAIMA, K.; ANOUAR, K. M.; NASSIMA, B. Evaluation of the Insecticidal Activity of the Aerial
Part of Pseudocytisus integrifolius (Salisb) Rehder on Grain Borer, Rhyzopertha dominica Fab. (Bostrychidae) and Wheat Weevil, Sitophilus granarius Linn. (Curculionidae). Journal of Life Sciences, New York, v. 7, n. 7, p. 700-704, 2013.

NÉRI, D. K. P. et al. Interação silício com inseticida regulador de crescimento no manejo da lagarta-docartucho Spodoptera frugiperda (J. E. Smith, 1797) (Lepidoptera: Noctuidae) em milho. Ciência e Agrotecnologia, Lavras, v. 29, n. 6, p. 1167-1174, 2005.

OGENDO, J. O. et al. Bioactivity of Ocimum gratissimum L. oil and two of its constituents against five insect pests attacking stored food products. Journal of Stored Products Research, Manhattan, v. 44 , n. 4 , p. $328-334,2008$

OLIVEIRA, M. S. S. et al. Eficiência de produtos vegetais no controle da lagarta-do-cartucho-domilho Spodoptera frugiperda (J. E. Smith, 1797) (Lepidoptera: Noctuidae). Ciência e Agrotecnologia, Lavras, v. 31, n. 2, p. 326-331, 2007.

PIMENTEL, M. A. G. et al. Resistance of storedproduct insects to phosphine. Pesquisa Agropecuária Brasileira, Brasília, v. 43, n. 12, p. 1671-1676, 2008.

PRATES, H. T. et al. Insecticidal activity of monoterpenes against Rhyzopertha dominica (F.) and Tribolium castaneum (Herbst). Journal of Stored Products Research, Manhattan, v. 34, n. 4, p. 243 249, 1998.

RINGUELET, J. A. et al. Actividad insecticida del aceite esencial de Lippia alba (Mill.) N. E. Brown sobre Tribolium castaneum Herbst. en granos de trigo (Triticum aestivum L.). Revista Brasileira de Agroecologia, Pelotas, v. 9, n. 2, p. 214-222, 2014.

ROZMAN, V.; KALINOVIC, I.; KORUNIC, Z. Toxicity of naturally occurring compounds of Lamiaceae and Lauraceae to three stored products insects. Journal of Stored Products Research, Manhattan, v. 43, n. 4, p. 349-355, 2007.

SCHEEPENS, P. et al. Storage of agricultural products. Wageningen: CTA, 2011.85 p. 